\title{
Introgressive hybridization and phylogenetic relationships between Norway, Picea abies (L.) Karst., and Siberian, P. obovata Ledeb., spruce species studied by isozyme loci
}

\author{
KONSTANTIN V. KRUTOVSKII*广 \& FRITZ BERGMANN \\ †Laboratory of Population Genetics, N. I. Vavilov Institute of General Genetics, Russian Academy of Sciences, GSP-1 \\ Moscow 117809 B-333, Russia and $\ddagger$ Department of Forest Genetics and Forest Tree Breeding, Georg-August University \\ of Göttingen, Büsgenweg 2, 37077 Göttingen, Germany
}

\begin{abstract}
We analysed patterns of genetic variation at 26 isozyme loci across the area of two main forestforming spruce species in Eurasia, Norway spruce (Picea abies (L.) Karst.) and Siberian spruce ( $P$. obovata Ledeb.). Ten seed samples from distant parts of the $P$. abies $-P$. obovata area and from a supposedly wide zone of introgressive hybridization between them were investigated. A very high level of allozyme variation was found in populations of both species. As parameters of gene diversity, the mean number of alleles per locus, percentage of polymorphic loci $(95$ per cent criterion) and expected heterozygosity averaged $2.8,61.5$ and 0.252 for $P$. abies and 2.4, 61.5 and 0.213 for $P$. obovata, respectively. Norway and Siberian spruces turned out to be extremely similar genetically. We did not find any fixed allele differences between them, i.e. there were no diagnostic loci and only a few alleles could be characteristic of some populations. Cluster and multivariate analyses have shown that these two species should be considered as two closely related subspecies or two geographical races of one spruce species undergoing considerable gene exchange. Our genetic data agree with morphological data and confirm the existence of a wide zone of introgressive hybridization between Norway and Siberian spruces - perhaps the widest known among plants. The samples which, according to morphological and geographical data, were taken from presumably 'hybrid' populations showed 'intermediate' genetic characteristics. Clinal variation was suggested for some alleles, and the 'rare allele phenomenon', i.e. higher frequencies of rare and unique alleles, was observed in the 'hybrid' spruce populations.
\end{abstract}

Keywords: introgressive hybridization, isozyme loci, phylogeny, Picea abies (L.) Karst., Picea obovata Ledeb., population genetic structure.

\section{Introduction}

Norway spruce, Picea abies (L.) Karst., and Siberian spruce, $P$. obovata Ledeb., are traditional subjects of forest genetic and breeding research. However, until relatively recently, most investigations were limited to the use of morphological, physiological and other phenotypic traits with unclear modes of inheritance and unknown genetic control. Studies of isozyme genetic markers during the last two decades have resulted in additional valuable information on the genetic structure of Norway spruce (Tigerstedt, 1973,

${ }^{*}$ Correspondence. Temporary address: Department of Forest Science, Oregon State University, FSL 020, Corvallis, OR 973317501, U.S.A.
1979; Bergmann, 1974a, 1975; Bergmann \& Gregorius, 1979; Bergmann \& Ruetz, 1991; Lundkvist \& Rudin, 1977; Lundkvist, 1979; Brunel \& Rodolphe, 1985; Altukhov et al., 1986a, 1989; Paule, 1986; Paule \& Gömöry, 1973; Paule et al., 1990; Lagercrantz \& Ryman, 1990; Muona et al., 1990; Giannini et al., 1991a; Goncharenko \& Potenko, 1991; Morgante \& Vendramin, 1991; Gömöry, 1992; see also MüllerStarck et al., 1992 for review), the mating system in natural populations (Müller, 1977; Altukhov et al., 1989; Muona et al., 1990; Morgante et al., 1991), in plantations (Xie \& Knowles, 1992; Finkeldey, 1995) and in seed orchards (Cheliak et al., 1987; Paule et al., 1993), linkage between isozyme loci (Lundkvist, 1974a; Altukhov et al., 1986a; Muona et al., 1987; Geburek \& von Wuehlisch, 1989), and spruce conser- 
vation strategy (Finkeldey, 1992). Such information is necessary for the development of proper breeding, reforestation and gene conservation programmes (i.e. Bergmann, 1991; Wellendorf, 1991). Clinal genetic variation (Bergmann, 1978), the effects of air pollution on the genetic structure (Scholz \& Bergmann, 1984; Bergmann \& Scholz, 1985, 1987, 1989), and correlation between isozyme genotypes and morphological traits (Altukhov et al., 1986b; Bergmann \& Ruetz, 1991; von Wuehlisch \& Krusche, 1991) have also been studied in Norway spruce using isozyme loci.

However, most of the above-cited investigations have dealt with populations from the Central European part of the Norway spruce range, although this species, combined with Siberian spruce, has one of the largest parapatric areas among forest trees, covering nearly the entire area of Northern Eurasia and comparable only with Scots pine. Norway and Siberian spruces are considered to be different but very closely related species with a wide zone of introgressive hybridization along both sides of the Ural Mountains (Pravdin, 1975; Schmidt-Vogt, 1977). Both species have a great economic and ecological significance and are the subjects of intensive breeding programmes. In addition, the study of genetic processes in the zones of contact and introgression of these species may yield valuable data on spruce adaptation and evolution. Large-scale population genetic studies can also help to analyse the postglacial spruce distribution and clarify the routes of reinvasion. However, neither the eastern range of Norway spruce nor introgressive hybridization and phylogenetic relationships between Norway and Siberian spruces have been sufficiently studied using isozyme loci as genetic markers (Gömöry \& Paule, 1990; Goncharenko et al., 1990; Goncharenko \& Potenko, 1991).

Norway and Siberian spruce species have two main distinguishing morphological taxonomic traits - the shape and size of their cones and the shape of the cone scales (Pravdin, 1975). Norway spruce has large cones $(10-15 \mathrm{~cm})$ and egg-shaped serrated scales (Pravdin, 1975). In this paper we refer to this spruce type as 'pure' Norway spruce. According to Rubner (1953), it is found in three more or less isolated main parts of the P. abies area in Central Europe: (1) the Alpine southeastern European region (Italy, former Yugoslavia, Austria, Switzerland and southern Germany); (2) the Hercynic-Carpathian region (central and eastern Germany, western Poland, the Czech Republic, Slovakia, Rumania and Bulgaria); and (3) the NorthBaltic region (Scandinavian countries, eastern Poland, Byelorussia, western and central Russia). In contrast to Norway spruce, 'pure' Siberian spruce growing in northern Asia has smaller cones $(4-8 \mathrm{~cm})$ with oval, smooth scales (Pravdin, 1975). In the zone of intro- gressive hybridization, a range of 'intermediate' types of cone can be found. In fact, these traits are highly variable. However, if we ignore variation among high altitude varieties and some specific 'ecotypes', the 'pure' Norway spruce cone type is nearly dominant in Central Europe and the 'pure' Siberian spruce cone type becomes dominant east of the Ural Mountains. Whereas in trees from the extreme edges of the Norway-Siberian spruce area the two cone types look like qualitative species-diagnostic traits, in the zone of introgressive hybridization the cone traits seem to vary in a more quantitative way with clinal-like variation. It would be interesting to study how this morphological variation corresponds to other genetic variation.

Thus, the main objectives of our study are the following:

(1) to obtain data on the large-scale geographical distribution of allelic and genotype frequencies at 26 isozyme loci, and to estimate the levels of intra- and interpopulation genetic variation by studying Norway and Siberian spruce populations sampled from different parts of their ranges;

(2) to study the genetic structure of populations sampled from the zone of supposed introgressive hybridization between Norway and Siberian spruce;

(3) to estimate the level of genetic differentiation between Norway and Siberian spruces, as well as to reveal phylogenetic relationships between them and to find the most diagnostic species-specific alleles and loci.

\section{Material and methods}

\section{Plant material and sampling sites}

Designations and geographical origins of the populations of both spruce species investigated in the study are shown in Table 1. The samples consisted of ten bulked seed lots randomly collected from hundreds (Germany and Sweden) or even thousands of trees growing in each of the ten different, large natural populations. We suppose that these samples correctly represent the alleles of the original populations. Six samples were collected from the 'pure' Norway spruce populations (Germany, Sweden, Byelorussia, Ukraine, Russia-T and Russia-V), two samples from the supposed zone of introgressive hybridization (Ural and Komi), and two from the 'pure' Siberian spruce populations (Kazakhstan and Siberia). This sampling strategy was designed to maximize the chances of finding the most species- or population-characteristic or speciesspecific alleles and loci. 
Table 1 List of ten bulked spruce seed samples, indicating their designations and geographical origins

\begin{tabular}{lll}
\hline Geographical origin (country and name of region and/or nearest city) & Co-ordinate & Designation \\
\hline 'Pure' Picea abies & & Germany \\
$\quad$ Germany, Westerhof & $51^{\circ} 40^{\prime} \mathrm{N}, 10^{\circ} 30^{\prime} \mathrm{E}$ & Sweden \\
Sweden, Sörliden & $64^{\circ} 50^{\prime} \mathrm{N}, 19^{\circ} 50^{\prime} \mathrm{E}$ & Byelorussia \\
Byelorussia, Vitebsk & $55^{\circ} 20^{\prime} \mathrm{N}, 31^{\circ} 15^{\prime} \mathrm{E}$ & Ukraine \\
$\quad$ Ukraine, Chernigov & $51^{\circ} 20^{\prime} \mathrm{N}, 31^{\circ} 10^{\prime} \mathrm{E}$ & Russia- \\
$\quad$ West-Central Russia, Tula & $54^{\circ} 30^{\prime} \mathrm{N}, 37^{\circ} 40^{\prime} \mathrm{E}$ & Russia-V \\
$\quad$ West-Central Russia, Vyatsk & $58^{\circ} 40^{\prime} \mathrm{N}, 49^{\circ} 45^{\prime} \mathrm{E}$ & \\
'Hybrid' zone & & Ural \\
$\quad$ Central Russia, Ekaterinburg (Ural Mountains) & $56^{\circ} 50^{\prime} \mathrm{N}, 60^{\circ} 45^{\prime} \mathrm{E}$ & Komi \\
$\quad$ North-Central Russia, Komi Republic (North of Ural Mountains) & $63^{\circ} 20^{\prime} \mathrm{N}, 73^{\circ} 30^{\prime} \mathrm{E}$ & \\
'Pure'P. obovata & & Kazakhstan \\
$\quad$ Eastern Kazakhstan, Leninogorsk & $50^{\circ} 30^{\prime} \mathrm{N}, 83^{\circ} 50^{\prime} \mathrm{E}$ & Siberia \\
Eastern Russia, Krasnoyarsk (Eastern Siberia) & $51^{\circ} 20^{\prime} \mathrm{N}, 92^{\circ} 40^{\prime} \mathrm{E}$ & \\
\hline
\end{tabular}

\section{Electrophoretic analysis}

Isozyme seed haplotypes and, consequently, allele frequencies in a sample were inferred from isozyme phenotypes visualized after starch gel electrophoretic separation of haploid endosperm extracts and subsequent enzyme-specific staining. Fourteen isozyme systems encoded by 26 loci were employed. References to the inheritance and buffer systems used for isozyme separation are listed in Table 2. Detailed descriptions of electrophoretic conditions, specimen preparation, genetic interpretation of zymograms, designations of allozymes, alleles and loci have been given elsewhere (Altukhov et al., 1986a; Muona et al., 1987; Bergmann \& Scholz, 1989; Goncharenko \& Potenko, 1991). More than 135 seeds per locus, on average, were analysed for nearly every seed sample, which allowed us to search effectively for rare and unique alleles. We refer to alleles occurring in populations with a frequency less than 0.05 as rare ones, and to those occurring in one population or only in 'hybrid' populations as unique alleles.

\section{Data analysis}

Calculation of parameters of intra- and interpopulational genetic diversity (mean number of alleles per locus, $A$, percentage of polymorphic loci, $P$, mean heterozygosity expected from Hardy-Weinberg proportions, $\left.H_{\mathrm{e}}\right)$, estimation of genetic differentiation $\left(F_{\mathrm{ST}}\right.$ by Wright, 1978, and Nei, 1977) and genetic distances, clustering and construction of dendrograms of spruce populations were carried out using the IBM PC version 1.7 of the computer program BIosys-1 (Swofford \& Selander, 1981). Mean effective number of alleles per locus or gene pool diversity ( $\nu$, Gregorius, 1987), total population differentiation of the gene pool $\left(\delta_{\mathrm{T}}\right.$, Gregorius, 1987) and subpopulation genetic differentiation of the gene pool $\left(D_{j}\right.$ and $\delta$, Gregorius, 1984b; Gregorius \& Roberds, 1986) were computed using the GSED program by E. Gillet (unpublished). $D_{j}$ is specified as the amount of genetic differentiation of the gene pool of one (sub)population compared to the remainder of the total population for infinite population size (Gregorius, 1984b; Gregorius \& Roberds, $1986) . D_{j}$ is the proportion of alleles by which one spruce population differs from the remaining populations of the total Norway-Siberian spruce complex. This proportion is defined as

$D_{j}=\frac{1}{L} \sum_{l=1}^{L}\left(\frac{1}{2} \sum_{i=1}^{n_{1}}\left|p_{i l}-\bar{p}_{i l}\right|\right)$,

where $n$ and $L$ are the numbers of alleles and loci studied in population $j$, and $p_{i l}$ and $\bar{p}_{i l}$ are the frequencies of the alleles in the population $j$ and in the remaining populations of the total Norway-Siberian spruce complex, respectively. The subpopulation genetic differentiation is then defined by

$\delta=\sum_{j} c_{j} \cdot D_{j}$

where the weight $c_{j}$ expresses the relative size of the $j$ th (sub)population

$\left(\sum_{j} c_{j}=1\right)$

With our data we estimated different measures of genetic distance and used several methods of cluster- 
Table 2 Enzymes, loci, numbers of alleles and buffer systems

\begin{tabular}{|c|c|c|c|c|}
\hline Enzyme name (abbreviation, E.C. reference) & Locus & $N$ & Buffer system & Reference to the genetic control \\
\hline Acid phosphatase (APH, 3.1.3.2) & Aph-2 & 5 & $\begin{array}{l}\text { TCLiB, TC, } \\
\text { TVB }\end{array}$ & $\begin{array}{l}\text { Tigerstedt, 1973; Bergmann, 1974b; } \\
\text { Lundkvist, } 1975\end{array}$ \\
\hline Formate dehydrogenase (FDH, 1.2.1.2) & $F d h$ & 4 & TC & Authors' data \\
\hline Glutamate dehydrogenase (GDH, 1.4.1.3) & $G d h$ & 2 & $\begin{array}{l}\text { TCLiB, TC, } \\
\text { TVB }\end{array}$ & $\begin{array}{l}\text { Lundkvist, 1979; Brunel \& Rodolphe, } \\
\text { 1985; Altukhov et al., 1986a; Cheliak } \\
\text { et al., } 1987\end{array}$ \\
\hline $\begin{array}{l}\text { Glutamate-oxaloacetate transaminase } \\
\text { (GOT, 2.6.1.1) }\end{array}$ & $\begin{array}{l}\text { Got-1 } \\
\text { Got-2 } \\
\text { Got-3 }\end{array}$ & $\begin{array}{l}1 \\
4 \\
5\end{array}$ & $\begin{array}{l}\text { TCLiB, } \\
\text { TVB }\end{array}$ & $\begin{array}{l}\text { Lundkvist, 1979; Poulsen et al., 1983; } \\
\text { Brunel \& Rodolphe, 1985; Altukhov } \\
\text { et al., 1986a }\end{array}$ \\
\hline $\begin{array}{l}\text { Glucose-6-phosphate dehydrogenase } \\
\text { (G6PDH, 1.1.1.49) }\end{array}$ & G6pdh-1 & 4 & $\mathrm{TC}$ & Altukhov et al., 1986a \\
\hline Isocitrate dehydrogenase (IDH, 1.1.1.42) & $\begin{array}{l}\text { Idh-1 } \\
\text { Idh-2 }\end{array}$ & $\begin{array}{l}4 \\
4\end{array}$ & $\begin{array}{l}\text { TC, TVB, } \\
\text { TCLiB }\end{array}$ & $\begin{array}{l}\text { Altukhov et al., 1986a; Muona et al., } \\
1987\end{array}$ \\
\hline Leucine aminopeptidase (LAP, 3.4.11.1) & $\begin{array}{l}\text { Lap-1 } \\
\text { Lap-2 }\end{array}$ & $\begin{array}{r}10 \\
9\end{array}$ & TVB & Bergmann, 1973; Lundkvist, 1974b \\
\hline Malate dehydrogenase (MDH, 1.1.1.37) & $\begin{array}{l}M d h-1 \\
M d h-2 \\
M d h-3 \\
M d h-4 \\
M d h-m\end{array}$ & $\begin{array}{l}2 \\
4 \\
4 \\
3 \\
2\end{array}$ & $\mathrm{TC}$ & $\begin{array}{l}\text { Lundkvist, 1979; Brunel \& Rodolphe, } \\
\text { 1985; Altukhov et al., 1986a; Muona } \\
\text { et al., } 1987\end{array}$ \\
\hline $\begin{array}{l}\text { Menadion reductase (MNR, 1.6.99.2) or } \\
\text { diaphorase (DIA, 1.6.4.3.) or NADH- } \\
\text { dehydrogenase (NDH, 1.6.99.1) }\end{array}$ & $\begin{array}{l}\text { Mnr-4 or } \\
\text { Dia-4 or } \\
\text { Ndh-2 }\end{array}$ & 6 & $\begin{array}{l}\text { TCLiB, TC, } \\
\text { TVB }\end{array}$ & Authors' data; Muona et al., 1987 \\
\hline $\begin{array}{l}\text { Phosphoenolpyruvate carboxylase } \\
\text { (PEPC, 4.1.1.31) }\end{array}$ & Pepca & 4 & $\mathrm{TC}$ & Authors' data \\
\hline $\begin{array}{l}\text { 6-Phosphogluconate dehydrogenase } \\
\text { (6-PGDH, 1.1.1.44) }\end{array}$ & $\begin{array}{l}\text { 6-Pgd-1 } \\
\text { 6-Pgd-2 } \\
\text { 6-Pgd-3 }\end{array}$ & $\begin{array}{l}3 \\
6 \\
5\end{array}$ & $\mathrm{TC}$ & $\begin{array}{l}\text { Poulsen } \text { et al.,1983; Altukhov et al., } \\
\text { 1986a; Krutovskii \& Gafarov, 1987; } \\
\text { Morgante } \text { et al., 1989; Giannini } \text { et al., } \\
\text { 1991b }\end{array}$ \\
\hline Phosphoglucose isomerase (PGI, 5.3.1.9) & Pgi-2 & 7 & TCLiB & Poulsen et al., 1983 \\
\hline Phosphoglucomutase (PGM, 2.7.5.1) & $\begin{array}{l}\text { Pgm-1 } \\
\text { Pgm-2 }\end{array}$ & $\begin{array}{l}4 \\
7\end{array}$ & TVB & Poulsen et al., 1983 \\
\hline $\begin{array}{l}\text { Shikimic acid dehydrogenase } \\
\quad(\mathrm{SKDH}, 1.1 .1 .25)\end{array}$ & $\begin{array}{l}\text { Skdh-1 } \\
\text { Skdh-2 }\end{array}$ & $\begin{array}{l}3 \\
6\end{array}$ & TVB & $\begin{array}{l}\text { Authors' data; Muona et al., 1987; } \\
\text { Morgante et al., } 1989\end{array}$ \\
\hline
\end{tabular}

$N$, number of alleles observed. TC, Tris-citrate, $\mathrm{pH}$ 6.5-7.4 (Siciliano \& Shaw, 1976, with modifications); TCLiB, Tris-citrate/ Li-borate, pH 8.1 (Ashton \& Braden, 1961); TVB, Tris-EDTA-borate, pH 8.0 (Siciliano \& Shaw, 1976, with modifications).

ing, but almost all dendrograms resulted in nearly the same topology. Thus, we will present the most commonly used measures: Nei's $(1972,1978)$ genetic distance $D$, Cavalli-Sforza \& Edwards's (1967) chord distance, Gregorius's $(1974,1978,1984 \mathrm{a})$ distance $d_{\mathrm{o}}$, and the UPGMA-dendrogram based on the $D$ matrix (Sneath \& Sokal, 1973). The last two distances are metric ones and can be used in other clustering methods, such as the Wagner tree method (Farris, 1972), which unlike UPGMA does not require the assumption of equality of evolutionary rates. Thus, we will also present the phylogenetic tree obtained by the Wagner tree method of clustering based on the $d_{\mathrm{o}}$ matrix. This method minimizes the total branch length at each stage of clustering of OTUs. Nei's (1972) genetic distances matrix was also used for principal coordinate analysis of spruce populations and for analysis of correlation between geographical and distance matrices (normalized Mantel statistic $Z$ ) with the aid of the computer program NTSYS-pc (Rohlf, 1988). Pearson's linear and Spearman's rank correlations of allozyme allele frequencies with latitude and longitude of $P$. abies and $P$. obovata populations were studied using the SYSTAT statistical computer package (Wilkinson, 1987).

Differences in rare and unique allele frequencies between $P$. abies, $P$. obovata and 'hybrid' populations were estimated by Fisher's criterion statistics, 
$F=\left(\varphi_{1}-\varphi_{2}\right)^{2} \frac{N_{1} \cdot N_{2}}{N_{1}+N_{2}}$

where $\varphi_{1}=2 \arcsin \sqrt{p_{1}}$ and $\varphi_{2}=2 \arcsin \sqrt{p_{2}}, p_{1}$ and $p_{2}$ are the frequencies of rare or unique alleles, and $N_{1}$ and $N_{2}$ are the total number of alleles studied in populations 1 and 2 , respectively.

\section{Results and discussion}

\section{Levels of genetic diversity and intraspecific genetic differentiation among populations}

The genetic parameters estimated from allele frequencies of 26 isozyme loci are presented in Table 3 (the allele frequencies are available on request). Expected heterozygosity $\left(H_{\mathrm{e}}\right)$, calculated from corresponding Hardy-Weinberg proportions, averaged 0.252 , ranging from 0.192 in the German population to 0.284 in the Swedish population of Norway spruce (Table 3). The mean number of alleles per locus $(A)$ was 2.8 , again with a minimum of 2.5 in the German population and a maximum of 2.9 in several other populations (Byelorussia, Ukraine and Russia-T). The average percentage of polymorphic loci $(P)$ was 61.5 and ranged from 53.8 per cent (Germany) to 65.4 per cent (Byelorussia, Ukraine and Sweden). The significantly lower level of genetic diversity in the German population compared to other Norway spruce populations agrees with previous data indicating that central European populations have consistently less genetic variability than north-eastern and Scandinavian populations (Lagercrantz \& Ryman, 1990; Bergmann, 1991). This may have resulted from a relatively recent decrease in effective population size ('bottleneck' effect) during the last glaciation, which is assumed for many Central European populations. An artificial origin of the German population cannot be completely excluded, although specialists consider this Westerhof population in the foothills of the Harz Mountains to be indigenous (Schmidt-Vogt, 1977).

Table 3 Genetic variation in ten populations of Picea abies and P. obovata determined at 26 isozyme loci

\begin{tabular}{|c|c|c|c|c|c|c|}
\hline Population name & $N \pm \mathrm{SE}^{1}$ & $A \pm \mathrm{SE}^{2}$ & $P, \%^{3}$ & $H_{\mathrm{e}} \pm \mathrm{SE}^{4}$ & $v^{5}$ & $D_{j}^{6}$ \\
\hline \multicolumn{7}{|l|}{ 'Pure' Picea abies } \\
\hline Germany & $132.8 \pm 6.7$ & $2.5 \pm 0.2$ & 53.8 & $0.192 \pm 0.038$ & 1.236 & 0.132 \\
\hline Sweden & $125.2 \pm 7.9$ & $2.8 \pm$ & 65.4 & $0.284 \pm 0.047$ & 1.3 & 4 \\
\hline Byelorussia & $137.5 \pm 7.2$ & 2.9 & 65.4 & $0.255 \pm 0.042$ & 1.3 & 0. \\
\hline Ukraine & $144.2 \pm 10.2$ & $2.9 \pm$ & 65.4 & $0.259 \pm 0.042$ & 1.349 & 0.0 \\
\hline Russia-T & 1 & 2.9 & & 0.2 & 1.3 & 0.054 \\
\hline Russia & 9 & $2.8=$ & 61 & 0.27 & 1. & 1.0 \\
\hline Mean & $138.2 \pm$ & $2.8=$ & 61.5 & & 1. & 0.084 \\
\hline \multicolumn{7}{|l|}{ 'Hybrid' zone } \\
\hline Ural & $41.4 \pm 7.9$ & $2.9 \pm 0.3$ & 65 & 0.2 & 1. & 0.072 \\
\hline Komi & $136.8 \pm 7.2$ & 2.9 & $5^{\prime}$ & 0.050 & 1 . & 0.106 \\
\hline \multicolumn{7}{|l|}{ 'Pure' P. obovata } \\
\hline Kazakhstan & $137.8 \pm 9.3$ & $2.5 \pm$ & 61 & 0.2 & 1.264 & 0.148 \\
\hline Siberia & 14 & $2.3 \pm$ & 61.5 & $0.216 \pm 0.040$ & 1.274 & \\
\hline Mean & $140.6 \pm 11.9$ & $2.4 \pm$ & 61.5 & 40 & 1.269 & 0.141 \\
\hline \\
\hline \multirow{2}{*}{\multicolumn{7}{|c|}{$\begin{array}{l}2 \text { Mean number of alleles per locus and standard error }(\mathrm{SE}) \text {. } \\
{ }^{3} \text { Percentage of polymorphic loci (a locus is considered polymorphic if the frequency } \\
\text { of the most common allele does not exceed } 0.95 \text { ). }\end{array}$}} \\
\hline & & & & & & \\
\hline \multirow{3}{*}{\multicolumn{7}{|c|}{$\begin{array}{l}{ }^{4} \text { Mean heterozygosity expected from Hardy-Weinberg proportions (unbiased } \\
\text { estimate according to Nei, 1978) and standard error }(\mathrm{SE}) \text {. It equals total population } \\
\text { differentiation of the gene pool, } \delta_{\mathrm{T}} \text {, for large sample size (Gregorius, 1987). } \\
{ }^{5} \text { Mean effective number of alleles per locus or gene pool diversity (Gregorius, } \\
\text { 1987). }\end{array}$}} \\
\hline & & & & & & \\
\hline & & & & & & \\
\hline \multicolumn{7}{|c|}{$\begin{array}{l}{ }^{6} \text { The amount of genetic differentiation of the gene pool of one subpopulat } \\
\text { remainder of the total population for infinite population size (Gregorius, } 1 \\
\text { Gregorius \& Roberds, 1986). }\end{array}$} \\
\hline
\end{tabular}


Siberian spruce populations have less genetic diversity than Norway spruce. However, our preliminary data do not allow us to conclude whether it is a speciesspecific phenomenon and we need to confirm this by further studies.

Because of the differences in allele frequencies at several loci between Norway and Siberian spruces the 'hybrid' populations have the highest levels of genetic diversity among all populations studied.

The data obtained confirm the high level of intrapopulation variation found in previous studies on spruce species, including Norway and Siberian spruce (Table 4), as well as in conifers in general (MüllerStarck et al., 1992). According to the published data on Norway and Siberian spruce, our values of genetic diversity exceed all previous estimates based on a similar number of loci. However, such comparisons should be made with caution because the sets of isozyme loci used are not the same in every case. On the whole, our data correspond quite well with previously published data.

Some rare alleles of the loci $F d h$ and $M n r-4$ were specific to one or a few populations of Siberian spruce, and some rare and unique alleles of loci $A p h-2, F d h$, Got-2, Got-3, G6pdh-1, Idh-2, Lap-2, Mnr-4, Pepca and $6-P g d-2$ were specific to one or a few populations of Norway spruce.

Allele frequencies of some loci vary clinally across the whole Norway-Siberian spruce area (Table 5). To answer the question of whether this is the result of gradient selection on these alleles or the result of gradual gene flow between Norway and Siberian spruce through incomplete isolation-by-distance, additional investigations are necessary.

Genetic differentiation among populations was analysed using $F$-statistics (Nei, 1977; Wright, 1978) and the $\delta$-measure (Gregorius, 1984b; Gregorius \& Roberds, 1986). In spite of the very wide distribution of the populations studied, levels of intraspecific genetic differentiation among populations were comparatively low - only about 1-4 per cent of the total intraspecific isozyme gene variation resulted from interpopulation variation $\left(F_{\mathrm{ST}}=0.044\right.$ for Norway spruce and $F_{\mathrm{ST}}=0.011$ for Siberian spruce) and the overwhelming proportion of the total variation, over 95 per cent, belonged to intrapopulation variation (Table 6). The loci Gdh, G6pdh-1 and Pgm-2 of Norway spruce, and $P g m-2$ of Siberian spruce make the most significant contributions to the intraspecific differentiation of these species (Table 6). Since these same loci also show clinal variation (Table 5), geographical variation in these loci should be studied in detail in future searches for possible adaptive loci.

Genetic distances between populations were also small (e.g. for Nei's (1972) genetic distance between populations of Norway spruce, $D$ averaged 0.020 and ranged between 0.007 and 0.051 (Table 7)). These values agree with the calculations carried out on three other spruce species. Nei's genetic distance averaged 0.012 among six populations of $P$. glauca (Yeh \& Arnott, 1986; Alden \& Loopstra, 1987), 0.013 among 32 populations of $P$. mariana (O'Reilly et al., 1985; Yeh et al., 1986; Boyle \& Morgenstern, 1987), and 0.014 among 13 populations of $P$. sitchensis (Yeh \& El-Kassaby, 1980; Yeh, 1981; Yeh \& Arnott, 1986). We have also summarized data on interpopulation genetic differentiation of these three spruce species using $F_{\mathrm{ST}}$ or analogous $G_{\mathrm{ST}}$ parameters of differentiation (Table 4). These values ranged from 0.010 to 0.079 (average 0.048 ) and are very similar to our data (Table 6).

The parameter $D_{j}$ gives a good estimation of the contribution of each population to the total differentiation of the Norway-Siberian spruce complex (Table 3). The populations of Germany (Norway spruce) and Kazakhstan (Siberian spruce), from the remote parts of the Norway-Siberian spruce area, made the greatest contribution to the total genetic differentiation and turned out to be the most divergent. On the other hand, Russian populations exhibited the smallest differentiation and their gene pools were the most 'representative' of the total gene composition, which, hypothetically, can be explained by their geographical proximity to the ancient refuge in the Central Russian area. From this point of view, they can be considered as the most original populations keeping most of the 'ancient' spruce variation. Gene flow from the extreme populations could be another explanation of the weak differentiation of the Russian populations, taking into account their central position. However, both considerations are rather speculative because of the generally low $F_{\mathrm{ST}}$ levels.

The low levels of interpopulation differentiation obtained for allozyme loci of Norway-Siberian spruce are usual for conifers. Such factors as outcrossing, wind-pollination, seed dispersal by wind (most conifers) or by birds (stone pines, some white pines and pinyons), wide continuous ranges, high population density and large effective size are expected to reduce the influence of genetic drift and, therefore, decrease heterogeneity of allele frequencies and interpopulation genetic differentiation for allozyme alleles that are largely equivalent selectively (Hamrick et al., 1981; Hamrick, 1983; Loveless \& Hamrick, 1984; Hamrick \& Loveless, 1986; Hamrick \& Godt, 1989). On the other hand, recent analysis of isozyme alleles in forest tree populations suggests that isozymes of the primary metabolism have been optimized during evolutionary epochs and, therefore, are present in all populations, and that major allozyme polymorphism (where there is 


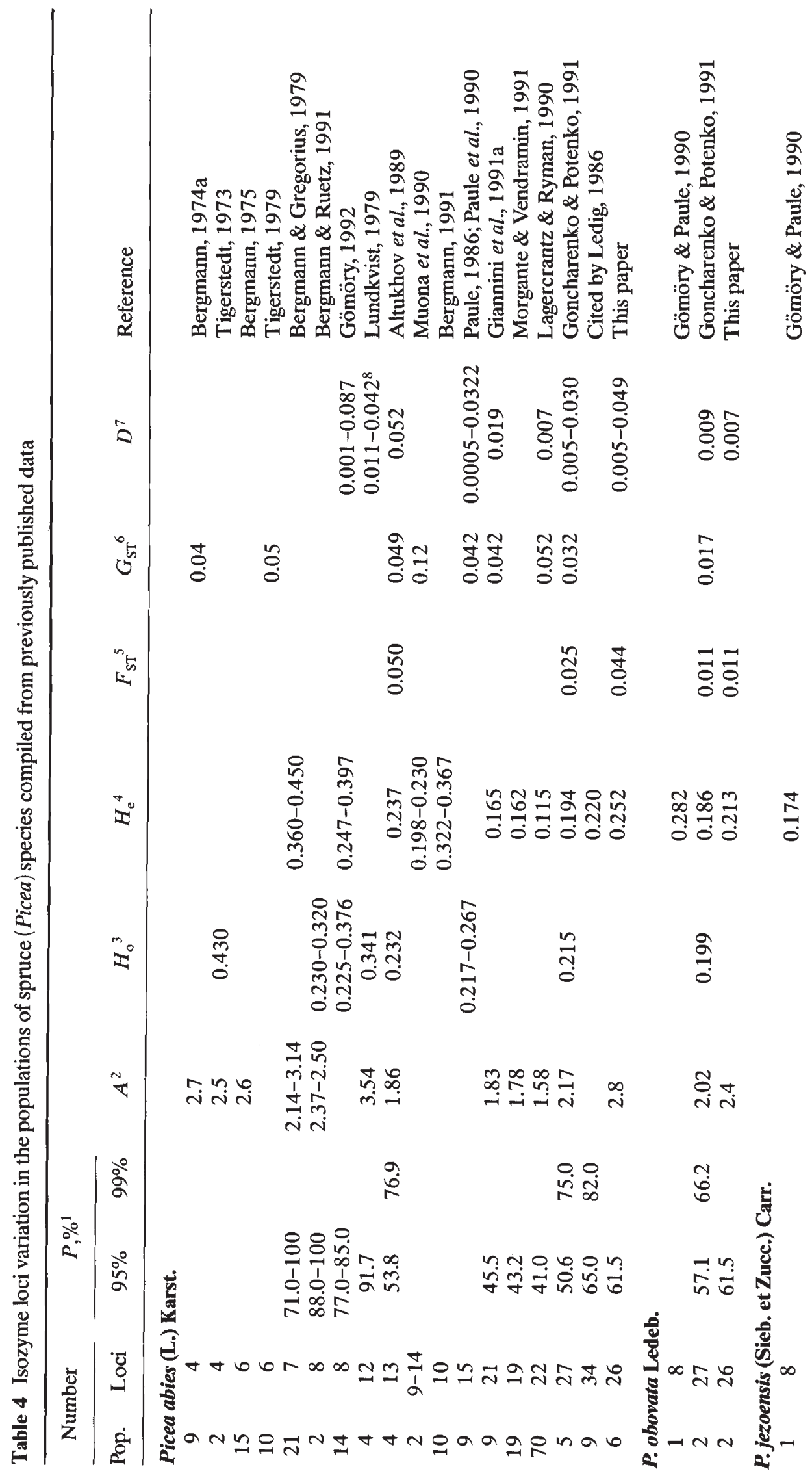

(c) The Genetical Society of Great Britain, Heredity, 74, 464-480. 


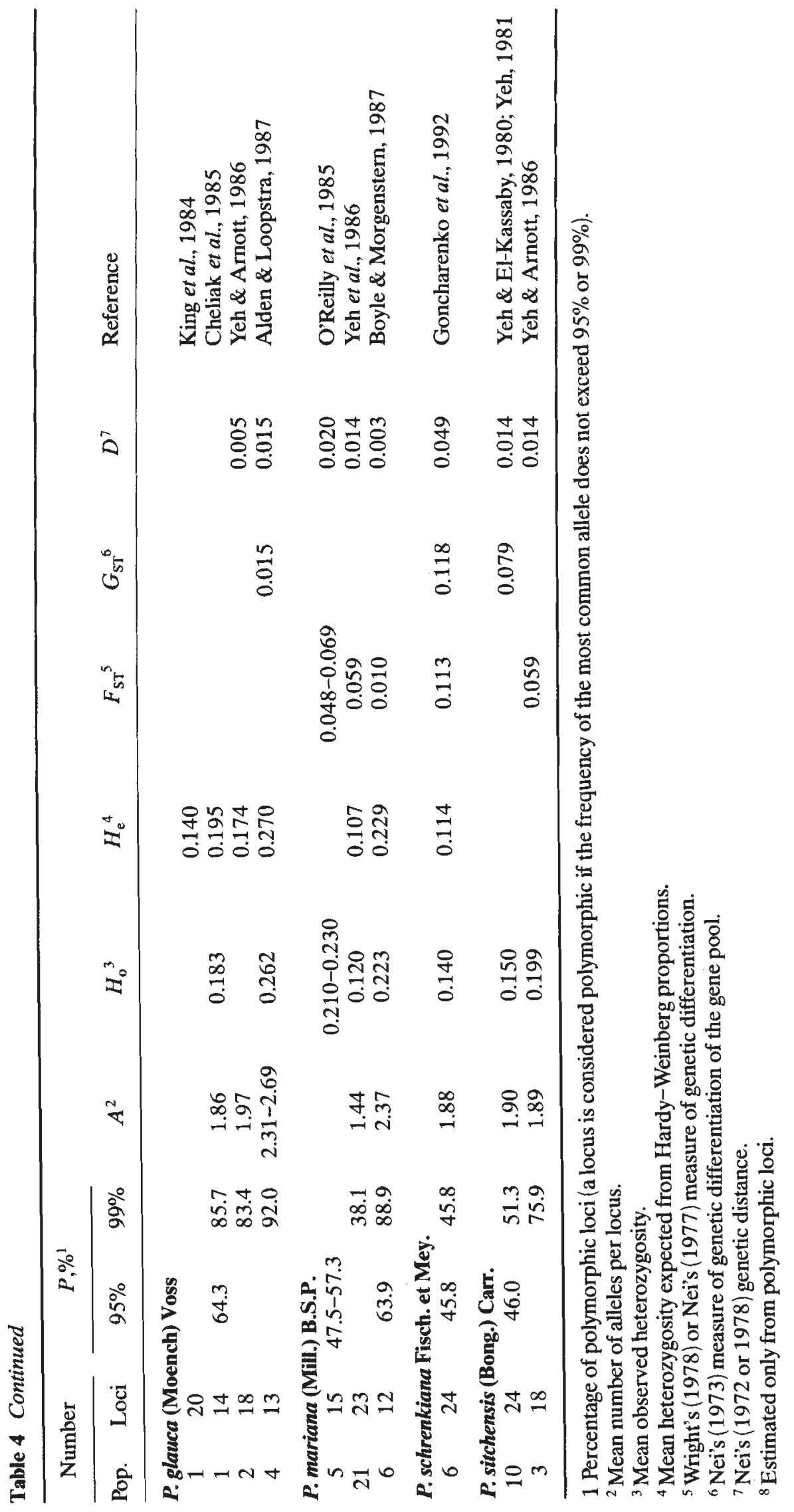


Table 5 Correlations $(\boldsymbol{r})$ of allozyme allele frequencies with latitude and longitude of ten Picea abies and $P$. obovata populations

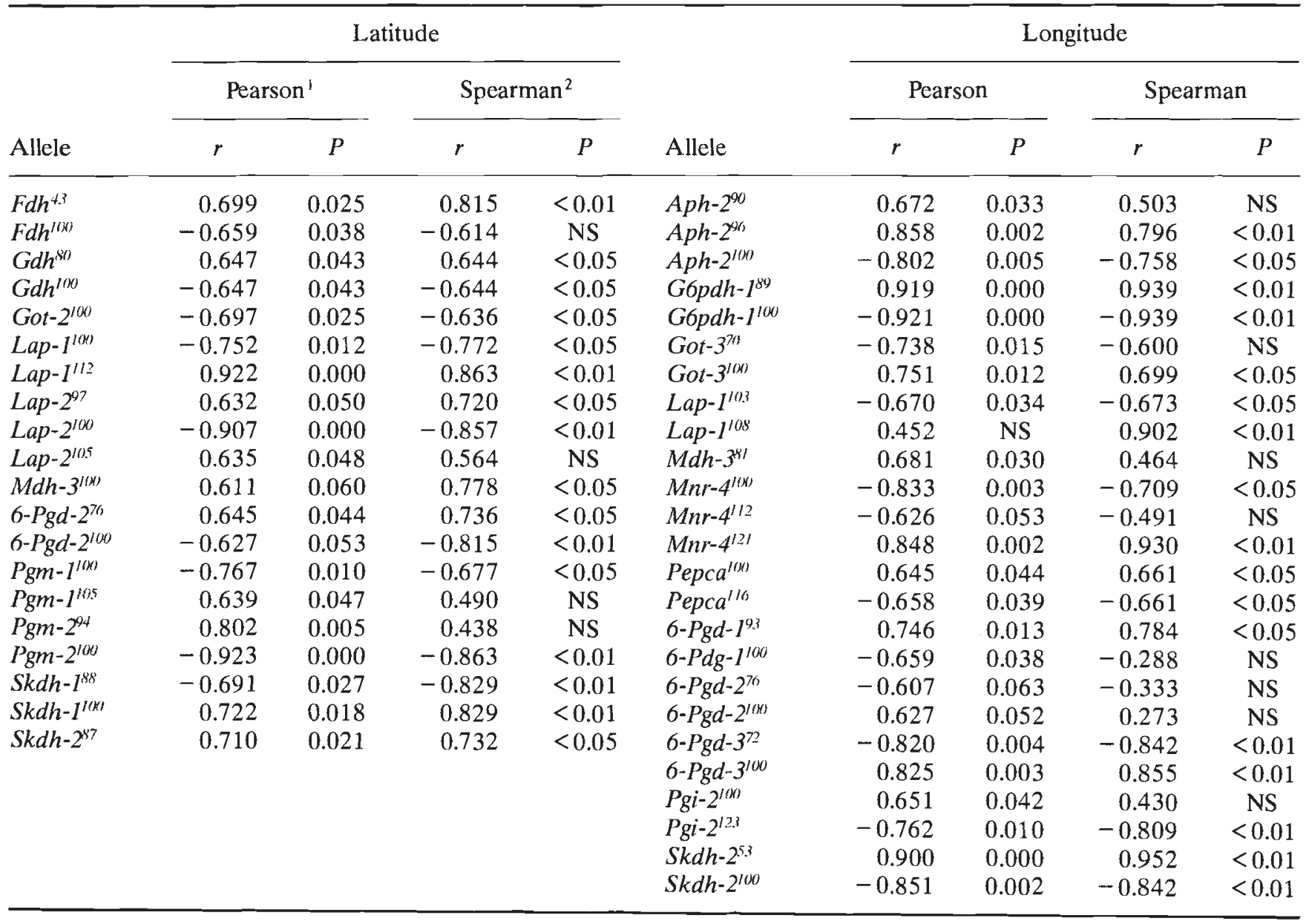

${ }^{1}$ Pearson's linear correlation.

${ }^{2}$ Spearman's rank correlation.

more than one prevalent allele in the population) is the result of heterozygote advantage arising from ontogenetic differentiation in enzyme function (Bergmann \& Gregorius, 1993; Gregorius \& Bergmann, 1994).

In spite of a generally low differentiation among spruce populations within species and the low values of genetic distances (Table 7), dendrograms based on these distances basically reflect the geographical origin of the spruce samples (Fig. 1). Moreover, the genetic similarity found between the Swedish population and some Central Russian populations of Norway spruce supports the hypothesis that this species immigrated from the Central Russian area into Scandinavia during the postglacial expansion (Schmidt-Vogt, 1977; Lagercrantz \& Ryman, 1990).

Principal coordinates analysis based on the matrix of Nei's genetic distances between spruce samples has also been performed (Fig. 2). This multidimensional analysis produced almost the same result as the cluster analysis. Genetic relationships between spruce popula- tions, graphically presented in the three-dimensional space of the first three principal coordinates, clearly reflected the actual geographical distribution of these populations (Fig. 2).

A statistically significant positive correlation between geographical and genetic distances has been found for Norway spruce populations $(r=0.62-0.78$; Table 8) indicating that long-distance migration with gene flow and gradually changing selection, at least at several allozyme loci, could play a significant role in genetic differentiation. Analogous results have also been obtained for many other conifers (see for review Krutovskii et al., 1994), including spruce (Lagercrantz \& Ryman, 1990; Giannini et al., 1991a).

We also analysed the correlation between geographical and Nei's distances for individual loci. Of the 26 loci studied only Aph-2, Fdh, Gdh, G6pdh-1, Lap-1, Lap-2, Mnr-4, 6-Pgd-2, 6-Pgd-3, Pgi-2 and Skdh-2 exhibit significant correlation (Table 8). This may suggest a selective influence on certain alleles. Patterns 
Table 6 Hierarchical $F_{\mathrm{ST}}$-analysis of allozyme allele variation among ten populations of Picea abies and $P$. obovata

\begin{tabular}{|c|c|c|c|c|c|c|c|c|c|c|c|}
\hline \multirow[b]{3}{*}{ Locus } & \multicolumn{6}{|c|}{ Without two populations from 'hybrid' zone } & \multicolumn{5}{|c|}{ Including two populations from 'hybrid' zone } \\
\hline & \multicolumn{3}{|c|}{ Population/Species } & \multirow[b]{2}{*}{$\begin{array}{c}\text { Species/ } \\
\text { Total }\end{array}$} & \multicolumn{2}{|c|}{ Population/Total } & \multirow[b]{2}{*}{$\begin{array}{c}\text { Population/ } \\
\text { Species }\end{array}$} & \multirow[b]{2}{*}{$\begin{array}{c}\text { Species/ } \\
\text { Total }\end{array}$} & \multicolumn{3}{|c|}{ Population/Total } \\
\hline & $\begin{array}{l}\text { Picea } \\
\text { abies }\end{array}$ & $\begin{array}{c}\text { Picea } \\
\text { obovata }\end{array}$ & Both & & $\begin{array}{c}\text { Wright, } \\
1978\end{array}$ & $\begin{array}{l}\text { Nei, } \\
1977\end{array}$ & & & $\begin{array}{c}F_{\mathrm{ST}}, \\
\text { Wright, } \\
1978\end{array}$ & $\begin{array}{c}F_{\mathrm{ST}} \\
\mathrm{Nei}, \\
1977\end{array}$ & $\begin{array}{c}\delta, \\
\text { Gregorius, } \\
1987\end{array}$ \\
\hline Aph-2 & 0.023 & 0.013 & 0.027 & 0.034 & 0.060 & 0.064 & 0.026 & 0.025 & 0.051 & 0.055 & 0.124 \\
\hline Fdh & 0.027 & 0.019 & 0.036 & 0.010 & 0.026 & 0.036 & 0.032 & 0.093 & 0.121 & 0.130 & 0.130 \\
\hline$G d h$ & 0.119 & 0.011 & 0.117 & 0.029 & 0.091 & 0.094 & 0.099 & 0.001 & 0.099 & 0.102 & 0.133 \\
\hline Got-2 & 0.016 & 0.000 & 0.023 & 0.004 & 0.019 & 0.022 & 0.015 & 0.001 & 0.014 & 0.017 & 0.017 \\
\hline Got-3 & 0.020 & 0.017 & 0.028 & $0.178^{*}$ & 0.201 & 0.204 & 0.027 & 0.141 & 0.164 & 0.167 & 0.180 \\
\hline G6pdh-1 & 0.162 & 0.011 & 0.203 & 0.198* & 0.361 & 0.363 & 0.179 & 0.188 & 0.333 & 0.335 & 0.267 \\
\hline$I d h-1$ & 0.041 & 0.008 & 0.044 & 0.005 & 0.039 & 0.042 & 0.069 & 0.010 & 0.060 & 0.063 & 0.076 \\
\hline$I d h-2$ & 0.006 & 0.003 & 0.008 & 0.003 & 0.005 & 0.009 & 0.008 & 0.003 & 0.005 & 0.008 & 0.009 \\
\hline Lap-1 & 0.056 & 0.003 & 0.060 & 0.012 & 0.071 & 0.075 & 0.055 & 0.012 & 0.066 & 0.070 & 0.240 \\
\hline Lap-2 & 0.048 & 0.000 & 0.052 & 0.008 & 0.045 & 0.051 & 0.071 & 0.001 & 0.071 & 0.077 & 0.181 \\
\hline Mdh-1 & 0.007 & 0.000 & 0.008 & 0.003 & 0.006 & 0.009 & 0.009 & 0.003 & 0.006 & 0.010 & 0.005 \\
\hline$M d h-2$ & 0.007 & 0.000 & 0.011 & 0.003 & 0.008 & 0.012 & 0.005 & 0.006 & 0.011 & 0.015 & 0.013 \\
\hline$M d h-3$ & 0.007 & 0.007 & 0.010 & 0.020 & 0.030 & 0.034 & 0.011 & 0.023 & 0.033 & 0.037 & 0.043 \\
\hline$M d h-m$ & 0.025 & 0.019 & 0.035 & 0.005 & 0.030 & 0.042 & 0.034 & 0.008 & 0.026 & 0.036 & 0.094 \\
\hline$M d h-4$ & 0.017 & 0.009 & 0.023 & 0.004 & 0.018 & 0.022 & 0.023 & 0.005 & 0.018 & 0.022 & 0.024 \\
\hline$M n r-4$ & 0.009 & 0.010 & 0.013 & $0.128^{*}$ & 0.140 & 0.142 & 0.011 & 0.104 & 0.114 & 0.116 & 0.197 \\
\hline Pepca & 0.029 & 0.000 & 0.039 & 0.005 & 0.043 & 0.049 & 0.035 & 0.002 & 0.037 & 0.044 & 0.047 \\
\hline $6-P g d-1$ & 0.012 & 0.005 & 0.012 & $0.071^{*}$ & 0.082 & 0.087 & 0.012 & 0.074 & 0.085 & 0.090 & 0.061 \\
\hline $6-P g d-2$ & 0.011 & 0.013 & 0.017 & $0.092^{*}$ & 0.107 & 0.110 & 0.014 & 0.077 & 0.090 & 0.093 & 0.139 \\
\hline $6-P g d-3$ & 0.054 & 0.005 & 0.068 & 0.038 & 0.104 & 0.107 & 0.063 & 0.038 & 0.099 & 0.102 & 0.123 \\
\hline Pgi-2 & 0.006 & 0.022 & 0.013 & 0.014 & 0.026 & 0.029 & 0.021 & 0.011 & 0.032 & 0.035 & 0.098 \\
\hline Pgm-1 & 0.010 & 0.005 & 0.014 & 0.003 & 0.011 & 0.015 & 0.009 & 0.003 & 0.012 & 0.015 & 0.023 \\
\hline Pgm-2 & 0.074 & 0.034 & 0.089 & 0.015 & 0.076 & 0.079 & 0.087 & 0.010 & 0.078 & 0.082 & 0.146 \\
\hline$S k d h-1$ & 0.005 & 0.000 & 0.002 & 0.030 & 0.032 & 0.035 & 0.003 & 0.035 & 0.038 & 0.041 & 0.036 \\
\hline$S k d h-2$ & 0.004 & 0.000 & 0.003 & $0.048^{*}$ & 0.051 & 0.054 & 0.004 & 0.037 & 0.041 & 0.044 & 0.086 \\
\hline Mean & 0.044 & 0.011 & 0.050 & 0.051 & 0.099 & 0.103 & 0.048 & 0.048 & 0.095 & 0.099 & 0.096 \\
\hline
\end{tabular}

*Most diagnostic loci (variation at these loci is mainly determined by allele frequency differences between $P$. abies and $P$. obovata).

of spatial differentiation seem to be the result of complex interaction of gene flow and selection. Distribution of genetic variability may be also affected by 'evolutionary footprints', such as, for example, spruce populations descendant from different refuges.

\section{Genetic differentiation between Norway and Siberian spruces and their phylogenetic relationships}

Genetic distances estimated between Norway and Siberian spruce were relatively small (Table 7 ). Nei's distance (1972) equalled $0.046-0.103$ (average 0.072). Such levels of differentiation correspond to that between subspecies or geographical races. For example, the genetic distance between two closely related North American spruce species $P$. glauca and P. sitchensis averaged 0.121 (Yeh \& Arnott, 1986).
Good crossability, high variation of morphological traits used as diagnostic features, existence of a wide zone of introgressive hybridization and the lack of species-specific diagnostic loci between Norway and Siberian spruce also suggest that they be considered as two subspecies or races (see also Lindquist, 1948; Schmidt-Vogt, 1974). The loci Got-3, G6pdh-1, Mnr-4, 6-Pgd-1, 6-Pgd-2 and $S k d h-2$ make the most significant contribution to interspecific differentiation of these spruces, but only 5 per cent of the whole Norway-Siberian spruce genetic variation results from interspecific differences (Table 6). According to $\delta$ values, Got-3, G6pdh-1, Lap-1, Lap-2, Mnr-4, and $P g m-2$ are, on the whole, the most diverged loci in the Norway-Siberian spruce complex (Table 6).

A relatively low level of divergence between Norway and Siberian spruce can be explained by the existence 
Table 7 Genetic distance between Picea abies and P. obovata populations and species

\begin{tabular}{|c|c|c|c|c|c|}
\hline $\begin{array}{l}\text { Measure of } \\
\text { genetic distance }\end{array}$ & Species & $\begin{array}{l}\text { Number of } \\
\text { populations }\end{array}$ & P. abies & 'Hybrid' & P. obovata \\
\hline \multirow[t]{3}{*}{ Nei (1978) unbiased } & Picea abies & 6 & $\begin{array}{c}0.019 \\
(0.005-0.049)\end{array}$ & & \\
\hline & 'Hybrid' & 2 & $\begin{array}{c}0.034 \\
(0.011-0.084)\end{array}$ & $\begin{array}{c}0.017 \\
(0.017-0.017)\end{array}$ & \\
\hline & P. obovata & 2 & $\begin{array}{c}0.071 \\
(0.044-0.102)\end{array}$ & $\begin{array}{c}0.048 \\
(0.033-0.061)\end{array}$ & $\begin{array}{c}0.007 \\
(0.007-0.007)\end{array}$ \\
\hline \multirow[t]{3}{*}{ Nei (1972) } & P. abies & 6 & $\begin{array}{c}0.020 \\
(0.007-0.051)\end{array}$ & & \\
\hline & 'Hybrid' & 2 & $\begin{array}{c}0.035 \\
(0.012-0.085)\end{array}$ & $\begin{array}{c}0.019 \\
(0.019-0.019)\end{array}$ & \\
\hline & P. obovata & 2 & $\begin{array}{c}0.072 \\
(0.046-0.103)\end{array}$ & $\begin{array}{c}0.049 \\
(0.035-0.063)\end{array}$ & $\begin{array}{c}0.008 \\
(0.008-0.008)\end{array}$ \\
\hline \multirow[t]{3}{*}{ Gregorius (1974) } & P. abies & 6 & $\begin{array}{c}0.092 \\
(0.061-0.151)\end{array}$ & & \\
\hline & 'Hybrid' & 2 & $\begin{array}{c}0.116 \\
(0.077-0.181)\end{array}$ & $\begin{array}{c}0.095 \\
(0.095-0.095)\end{array}$ & \\
\hline & P. obovata & 2 & $\begin{array}{c}0.173 \\
(0.140-0.198)\end{array}$ & $\begin{array}{c}0.159 \\
(0.134-0.180)\end{array}$ & $\begin{array}{c}0.068 \\
(0.068-0.068)\end{array}$ \\
\hline \multirow{3}{*}{$\begin{array}{l}\text { Cavalli-Sforza } \\
\& \text { Edwards (1967) } \\
\text { chord distance }\end{array}$} & P.abies & 6 & $\begin{array}{c}0.140 \\
(0.096-0.221)\end{array}$ & & \\
\hline & 'Hybrid' & 2 & $\begin{array}{c}0.162 \\
(0.113-0.263)\end{array}$ & $\begin{array}{c}0.136 \\
(0.136-0.136)\end{array}$ & \\
\hline & P. obovata & 2 & $\begin{array}{c}0.235 \\
(0.203-0.276)\end{array}$ & $\begin{array}{c}0.207 \\
(0.185-0.225)\end{array}$ & $\begin{array}{c}0.114 \\
(0.114-0.114)\end{array}$ \\
\hline
\end{tabular}

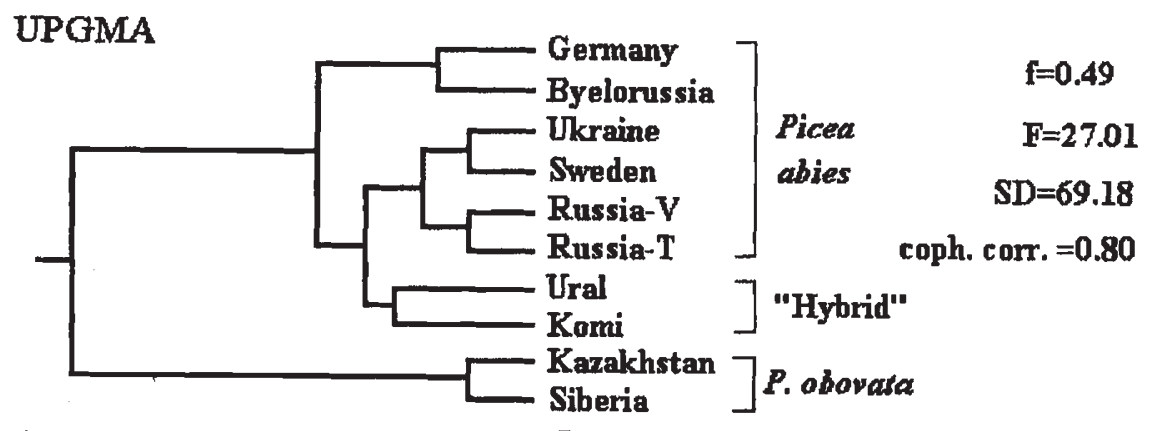

0.080 .070 .060 .050 .040 .030 .020 .010

Wagner Tree Method

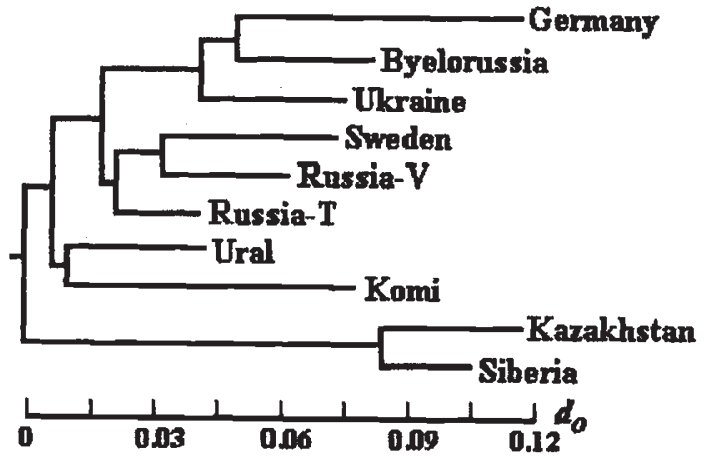

Fig. 1 UPGMA and Wagner Tree dendrograms of ten Picea abies and $P$. obovata populations based on 26 isozyme loci and $D\left(\right.$ Nei, 1972) and $d_{\mathrm{o}}$ (Gregorius, 1974, 1978, 1984a) genetic distance matrices, respectively. Goodness of fit statistics: $f$, summarized absolute difference between patristic and genetic distances (Farris, 1972); F, congruence measure by Prager \& Wilson (1976); SD, percent standard deviation (Prager \& Wilson, 1976); coph. corr., cophenetic correlation (Farris, 1972). 
Fig. 2 Principal Coordinate Analysis using $D$ (Nei, 1972) genetic distance matrix based on 26 isozyme loci allele frequencies of ten $P$. abies and $P$. obovata populations. 'Pure' Picea abies: Germ, Germany; Bye, Byelorussia; Ukr, Ukraine; Swe, Sweden; RusV and RusT, West-Central Russia. 'Hybrid' zone: H-Ural, Central Russia (Ural Mountains); H-Komi, North-Central Russia (North of Ural Mountains). 'Pure' Picea obovata: Kazak, Eastern Kazakhstan; Siber, Eastern Siberia (for more details see Table 1).

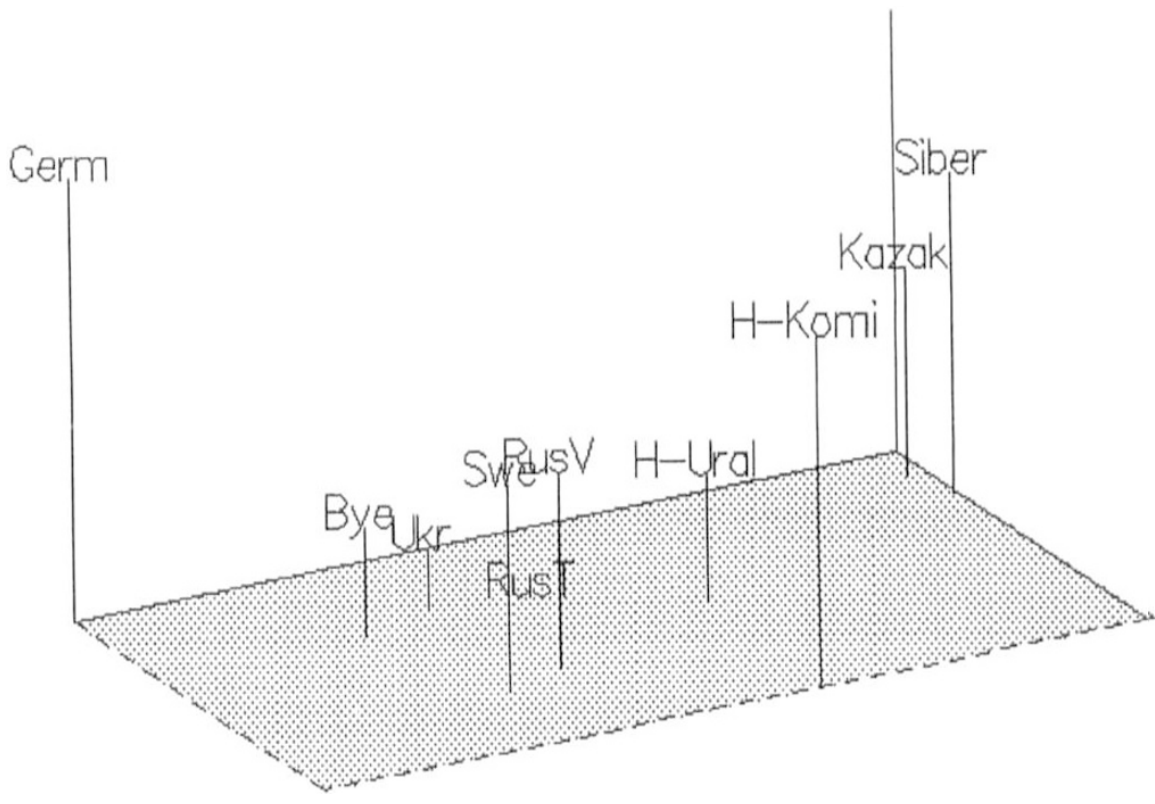

of several or many large common refuges of ancient spruce species which occupied a large area in Eurasia in the past. During glaciation, these large refuges could have conserved essential genetic variation and have thereby decelerated divergence and speciation processes. Subsequent reinvasion along with secondary contacts and hybridization between different populations could have prevented the establishment of new species if the duration of isolation was not sufficient to develop reproductive isolation mechanisms and genetic 'incompatibility'. Thus, the low level of divergence between Norway and Siberian spruce can be explained by the incomplete isolation within large refuges and the short duration of their existence. Nevertheless, a considerable amount of genetic difference accumulated during that time, because genetic distances between Norway and Siberian spruce are 3-4 times larger, on the average, than those between populations of the same species (Table 7) and are comparable with distances reported by other authors for subspecies or very closely related conifer species with introgressive hybridization (Dancik \& Yeh, 1983; Wheeler et al., 1983; Jacobs et al., 1984; Conkle et al., 1988; Millar et al., 1988).

\section{Introgressive hybridization between Norway and Siberian spruces}

The genetic structure of 'hybrid' populations (Komi and Ural) is quite different from that of other populations. The 'hybrid' populations have significantly higher levels of genetic variation than populations from the most remote parts of the Norway and Siberian spruce area. It is interesting to note that 'hybrid' popu- lations have 2-4 times more rare alleles and 4-10 times more unique alleles, than 'pure' $P$. abies and $P$. obovata populations (Table 9). This observation is well-known as the 'rare allele phenomenon' characteristic of interspecific hybrid zones (i.e. Barton et al., 1983; Barton \& Hewitt, 1985; Harrison, 1986; Cesaroni et al., 1992). Woodruff (1989) even introduced the term 'hybrizyme' for these unexpected allozymes occurring within hybrid zones.

One possible explanation of their origin may be intragenic recombination which can create a 'new' genetic variant among the progeny from heterozygous parents. Thus, new variants are more likely to arise in the progeny of highly heterozygous populations. Hybridization between populations with different allele frequencies will obviously increase individual heterozygosity.

Another explanation is connected with the phenomenon of 'hybrid dysgenesis'. One of its characteristics is an increase in mutability among hybrid progeny obtained from mating between distantly isolated populations. Nuclear-cytoplasmic control of different mobile genetic elements in the genome of such hybrids can be disrupted, favouring insertion mutagenesis (Woodruff, 1989).

Certainly, both of the above-mentioned mechanisms could be responsible for the high frequency of unique alleles in the hybrid populations. More investigations are needed to clarify this phenomenon.

The genetic relationships between populations from the zone of introgressive hybridization and other spruce populations also prove the existence of wide hybridization. According to dendrograms and multivariate analysis based on genetic distances, 'hybrid' 


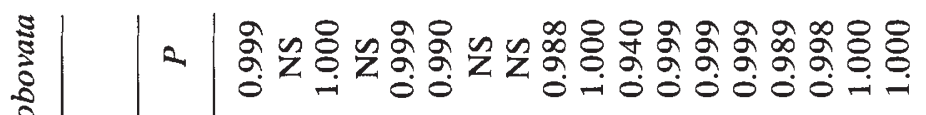

L. $\quad$ tn

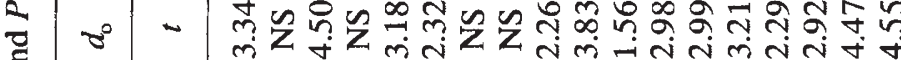

है

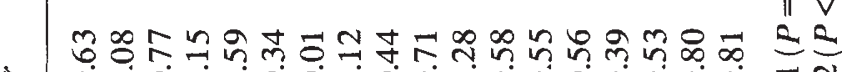

(1)

$\frac{1}{0}$

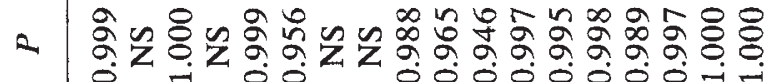



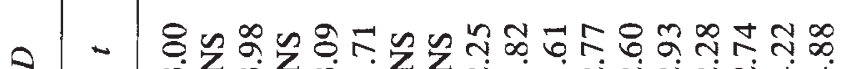

용

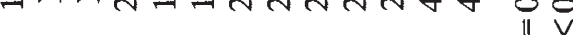

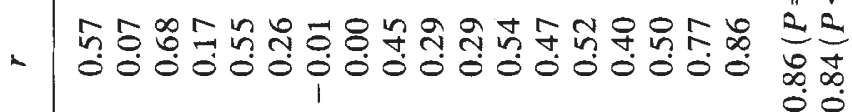

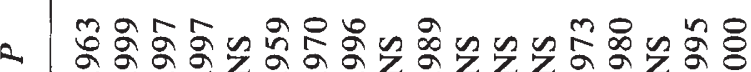
○

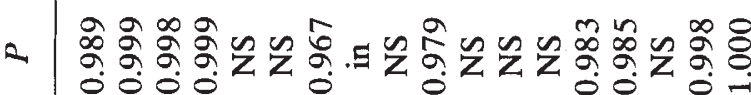

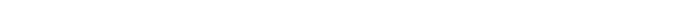

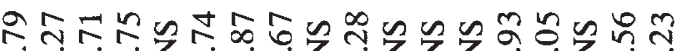

훙ㅇㅇ

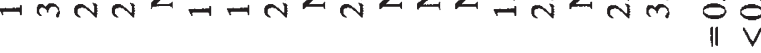

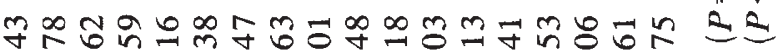

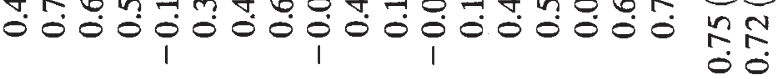

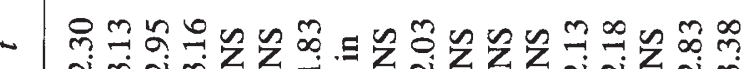

용

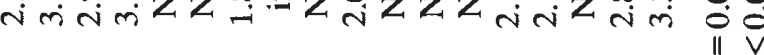

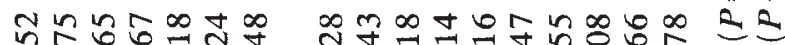

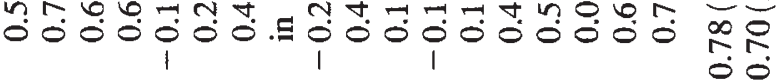

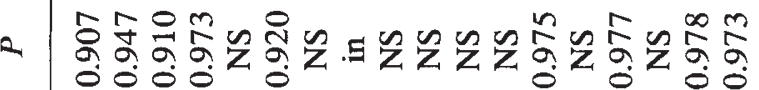

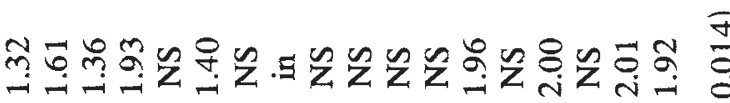

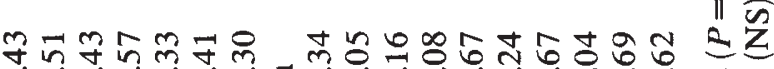

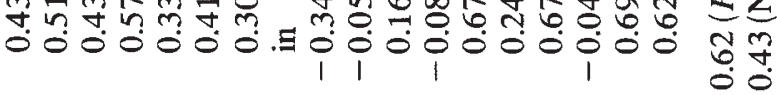

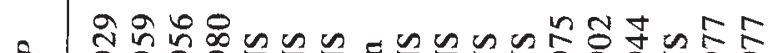

2

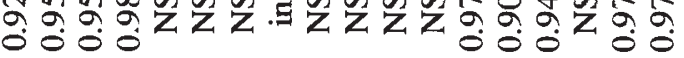

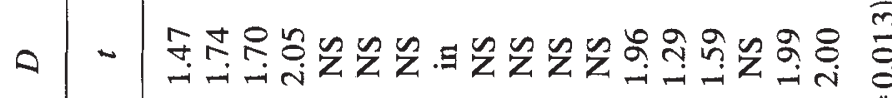

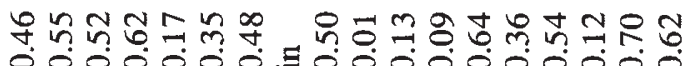
0000000.50000000000000

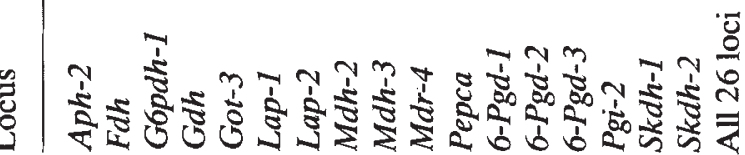

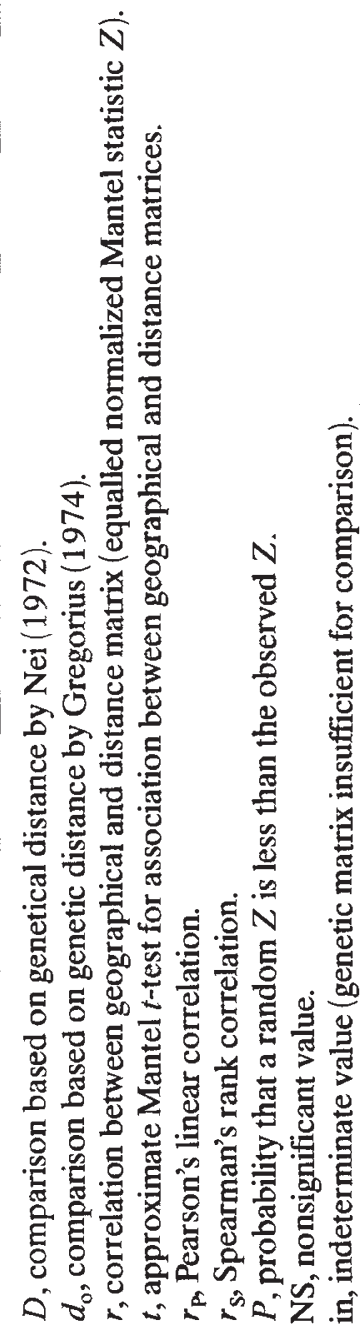


Table 9 Frequencies and statistics of rare and private alleles among Picea abies, P. obovata and 'hybrid' populations

\begin{tabular}{lccccc}
\hline Population & $\begin{array}{c}\text { Total number of } \\
\text { studied alleles }\end{array}$ & $\begin{array}{c}\text { Number of } \\
\text { rare alleles }\end{array}$ & $\begin{array}{c}\text { Frequency of } \\
\text { rare alleles }\end{array}$ & $\begin{array}{c}\text { Number of } \\
\text { unique alleles }\end{array}$ & $\begin{array}{c}\text { Frequency of } \\
\text { unique alleles }\end{array}$ \\
\hline $\begin{array}{l}\text { Picea abies } \\
\text { P. obovata }\end{array}$ & 18964 & 225 & 0.01187 & 8 & 0.00042 \\
'Hybrid' & 6197 & 32 & 0.00516 & 1 & 0.00016 \\
\hline
\end{tabular}

Fisher's criterion statistics, $F$

\begin{tabular}{lrrrrr}
\hline & \multicolumn{2}{c}{ Rare alleles } & & \multicolumn{2}{c}{ Private or unique alleles } \\
\cline { 2 - 3 } \cline { 5 - 6 } Compared populations & $F$ & & & \multicolumn{1}{c}{$F$} & \multicolumn{2}{c}{$P$} \\
\hline 'Hybrid' vs. Picea abies & 25.95 & $<0.001$ & & 9.34 & $<0.01$ \\
'Hybrid'vs. $P$. obovata & 70.06 & $<0.001$ & & 10.70 & $<0.01$ \\
Picea abies vs. $P$. obovata & 26.98 & $<0.001$ & & 0.92 & Nonsignificant \\
\hline
\end{tabular}

populations always occupy intermediate positions between 'pure' Norway and Siberian spruce (Fig. 1 and 2).

\section{Acknowledgements}

The first author is very grateful to the Alexander von Humboldt Foundation for financial support of his research in Germany. We thank V. V. Oreshkina (Central Forest Seed Station, Russia) for her kind assistance in providing seed samples, R. Finkeldey, E. Gillet, H.-R. Gregorius, H. H. Hattemer and an anonymous reviewer for helpful comments on the manuscript and greatly appreciate the help of M. van Egmond with electrophoretic analysis.

\section{References}

ALDEN, J. AND LOOPSTRA, c. 1987. Genetic diversity and population structure of Picea glauca on an altitudinal gradient in interior Alaska. Can. J. Forest Res., 17, 1519-1526.

ALTUKHOV, Yu, P., KRUTOVSKII, K. V., GAFAROV, N. I., DUKHAREV, V. A. AND MOROzov, G. P. 1986a. Allozyme variability in a natural population of Norway spruce (Picea abies [L.] Karst.). I. Polymorphic systems and mechanisms of their genetic control. Genetika (Russian), 22, 2135-2151 (translated into English as Soviet Genetics (1987), 22, 1028-1040).

ALTUKHOV, YU. P., GAFAROV, N. 1., KRUTOVSKII, K. V. AND DUKHAREV, V. A. 1986 b. Allozyme variability in a natural population of Norway spruce (Picea abies [L.] Karst.). III. Correlation between levels of individual heterozygosity and relative number of inviable seeds. Genetika (Russian), 22, 2825-2830 (translated into English as Soviet Genetics (1987), 22, 1580-1585).

ALTUKHOV, Yu. P., KRUTOVSKII, K. V., DUKHAREV, V, A., LARIONOVA, A. Ya., POLTTOV, D. V. AND RYABOKON, S. M. 1989. Biochemical population genetics of wood forest species. In: Forest Genetics, Breeding and Physiology of Woody Plants. Proceedings of the IUFRO International Symposium (September, 24-30, 1989, Voronezh, USSR), pp. 21-29, Moscow.

ASHTON, G. C. AND BRAden, A. W. H. 1961. Serum $\delta$-globulin polymorphism in mice. Aust. J. Biol. Sci., 14, 248-253.

BARTON, N. H. AND HEWITT, G. M. 1985. Analysis of hybrid zones. Ann. Rev. Ecol. Syst., 16, 113-148.

BARTON, N. H., HALLIDAY, R. B. AND HEWITT, G. M. 1983. Rare electrophoretic variants in a hybrid zone. Heredity, 50 , 139-146.

Bergmann, F. 1973. Genetische Untersuchungen bei Picea abies mit Hilfe der Isoenzym-Identifizierung. II. Genetische Kontrolle von Esterase- und Leucinaminopeptidase-Isoenzymen im haploiden Endosperm ruhender Samen. Theor. Appl. Genet., 43, 222-225.

bergmann, F. 1974a. Genetischer Abstand zwischen Populationen. II. Die Bestimmung des genetischen Abstands zwischen europäischen Fichtenpopulationen (Picea abies) auf der Basis von Isoenzym-Genhäufigkeiten. Silvae Genet., 23, 28-32.

BERGMANN, F. 1974b. The genetics of some isoenzyme systems in spruce endosperm (Picea abies). Genetika, 6, 353-360.

BERGMANN, F. 1975. Herkunfts-Identifizierung von Forstsaatgut auf der Basis von Isoenzym-Genhäufigkeiten. Allgemeine Forst- und Jagdzeitung, 146, 191-195.

BERGMANN, F. 1978. The allelic distribution at an acid phosphatase locus in Norway Spruce (Picea abies) along similar climatic gradients. Theor. Appl. Genet., 52, 57-64.

BERGMANN, F. 1991. Causes and consequences of speciesspecific genetic variation patterns in European forest tree species: examples with Norway spruce and silver fir. In: Müller-Starck, G. and Ziehe, M. (eds) Genetic Variation in European Populations of Forest Trees, pp. 192-204. J. D. Sauerländer's Verlag, Frankfurt am Main.

BERGMANN, F. AND GREGORIUS, H.-R. 1979. Comparison of the genetic diversities of various populations of Norway

(c) The Genetical Society of Great Britain, Heredity, 74, 464-480. 
Spruce (Picea abies). In: Proceedings of the Conference on Biochemical Genetics of Forest Trees, pp. 99-107. Umeå.

BERGMANN, F. AND GREGoriUs, H.-R. 1993. Ecogeographical distribution and thermostability of isocitrate dehydrogenase (IDH) alloenzymes in European silver fir (Abies alba). Biochem. Syst. Ecol., 21, 597-605.

BERGMANN, F. AND RUETZ, w. 1991. Isozyme genetic variation and heterozygosity in random tree samples and selected orchard clones from the same Norway spruce populations. For. Ecol. Manag., 46, 39-48.

BERGMAN, F. AND SCHOLZ, F. 1985. Effects of selection pressure by $\mathrm{SO}_{2}$ pollution on genetic structure of Norway Spruce (Picea abies). In: Gregorius, H.-R. (ed.) Population Genetics in Forestry, Lecture Notes in Biomathematics, vol. 60, pp. 267-275. Springer-Verlag, Berlin.

BERGMANN, F. AND SCHOLZ, F. 1987. The impact of air pollution on the genetic structure of Norway spruce. Silvae Genet., 36, 80-83.

BERGMANN, F. AND SCHOLZ, F. 1989. Selection effects of air pollution in Norway spruce (Picea abies) populations. In: Scholz, F., Gregorius, H.-R. and Rudin, D. (eds) Genetic Effects of Air Pollutants in Forest Tree Populations, pp. 143-160. Springer-Verlag, Berlin.

BOYLE, T. J. B. AND MORGENSTERN, E. K. 1987. Some aspects of the population structure of Black spruce in Central New Brunswick. Silvae Genet., 36, 53-60.

BRUNEL, D. AND RoDOLPHE, F, 1985. Genetic neighborhood structure in a population of Picea abies L. Theor. Appl. Genet., 71, 101-110.

CAVALli-SFORZA, L. L. AND EDWARds, A. W. F. 1967. Phylogenetic analysis: models and estimation procedures. Am. J. Hum. Genet., 19, 233-257.

CESARonl, D., ALlEGRUCCl, G. AND SBordonl, v. 1992. A narrow hybrid zone between two crayfish species from a Mexican cave. J. Evol. Biol., 5, 643-659.

CHELIAK, W. M., PITEL, J. A. AND MURRAY, G. 1985. Population structure and the mating system of white spruce. Can. J. Forest Res., 15, 301-308.

CHELIAK, W. M., SKRøPPA, T. AND PITEL, J. A. 1987. Genetics of the polycross. I. Experimental results from Norway Spruce. Theor. Appl. Genet., 73, 321-329.

CONKLE, M. T., SCHILLER, G. AND GRUNWALD, C. 1988. Electrophoretic analysis of diversity and phylogeny of Pinus brutia and closely related taxa. Syst. Bot., 13, 411-424.

DANCIK, B. P. AND YEH, F. C. 1983. Allozyme variability and evolution of lodgepole pine (Pinus contorta var. latifolia) and jack pine (Pinus banksiana) in Alberta. Can. J. Genet. Cytol., 25, 57-64.

FARR1S, J. S. 1972. Estimating phylogenetic trees from distance matrices. Am. Nat., 106, 645-668.

FINKELDEY, R. 1992. Auswahlkriterien und Anlage genetischer Ressourcen bei der Fichte (Picea abies [L.] Karst.). Forstarchiv, 63, 25-32.

FINKELDEY, R. 1995. Homogeneity of pollen allele frequencies of single seed trees in Picea abies (L.) Karst. plantations. Heredity, 74, 451-463.

GEBUREK, Th. AND VON WUEHLISCH, G. 1989. Linkage analysis of isozyme gene loci in Picea abies (L.) Karst. Heredity, 62, 185-191.
GlanniNı, R., MoRGANTE, M. AND VEndRAmin, G. G. 1991a. Allozyme variation in Italian populations of Picea abies (L.) Karst. Silvae Genet., 40, 160-166.

GiANNINI, R., MORGANTE, M. AND VENDRAMIN, G. G. 1991b. A putative gene duplication in Norway spruce for 6PGD and its phylogenetic implications. In: Fineschi, S., Malvolti, M. E., Cannata, F. and Hattemer, H. H. (eds) Biochemical Markers in the Population Genetics of Forest Trees, pp. 23-29. SPB Academic Publishing bv, The Hague.

GONCHARENKO, G. G. AND POTENKo, v. v. 1991. Genetic variability and differentiation in Norway spruce (Picea abies [L.] Karst.) and Siberian spruce (Picea obovata Ledeb.) populations. Genetika (Russian), 27, 1759-1772 (translated into English as Soviet Genetics (1992), 27, 1235-1246).

GONCHARENKO, G. G., POTENKO, v. V., SLOBODYAN, J. N. AND SIDOR, A. 1. 1990. Genetic and taxonomic relations between Picea abies (L.), P. montana Schur and $P$. obovata Ledeb. Doklady A kademii Nauk BSSR (Russian), 34, 361-364.

GONCHARENKO, G. G., POTENKO, v. V. AND ABDYGANYEV, N. 1992. Variation and differentiation in natural populations of Tien-Shan spruce (Picea schrenkiana Fisch. et Mey). Genetika (Russian), 28, 83-96 (translated into English as Soviet Genetics (1992), 28, 1446-1457).

GOMORY, D. 1992. Effect of stand origin on the genetic diversity of Norway spruce (Picea abies [L.] Karst.) populations. For. Ecol. Manag., 54, 215-223.

GÖMÖRY, D. AND PAULE, L. 1990. Sravnenie geneticheskoi izmenchivosti i skhodstva populyacij eli iz territorii Slovakii i SSSR. In: Intenzifikacia pestovania smrekovych porastov s ohladomna ekologicke podmienky, pp. 2-12. (Russian.) VSLD-MLTI, Zvolen-Moskva.

GREGORIUS, H.-R. 1974. On the concept of genetic distance between populations based on gene frequencies. In: Proc. IUFRO Joint Meeting of Working Parties on Popul. and Ecol. Genet., Breed Theory and Progeny Testing, SO2.04.1-3, Stockholm, pp. 17-26.

GREGORIUS, H.-R. 1978. The concept of genetic diversity and its formal relationship to heterozygosity and genetic distance. Math. Biosci., 41, 253-271.

GREGORIUS, H.-R. 1984a. A unique genetic distance. Biometrical J., 26, 13-18.

GREGORIUS, H.-R. 1984b. Measurement of genetical differentiation in plant populations. In: Gregorius, H.-R. (ed.) Population Genetics in Forestry, Lecture Notes in Biomathematics, vol. 60, pp. 276-285. Springer-Verlag, Berlin.

GREGORIUS, H.-R. 1987. The relationship between the concepts of genetic diversity and differentiation. Theor. Appl. Genet., 74, 397-401.

GREgorius, H.-R. AND BERGMANN, F. 1994. Analysis of isoenzyme genetic profiles observed in forest tree populations. In: Proceedings of the International Symposium on Population Genetics and Gene Conservation of Forest Trees. SPB Academic Publishing bv., The Hague. (In press.)

GREGORIUS, H.-R. AND ROBERDS, J. H. 1986. Measurement of genetical differentiation among subpopulations. Theor. Appl. Genet., 71, 826-834.

HAMRICK, J. L. 1983. The distribution of genetic variation 
within and among natural plant populations. In: Chambers, S. and Schonewald-Cox, C. (eds) Genetics and Wild Population Management, pp. 335-349 (and Appendix, pp. 501-509). Addison Wesley, Reading.

HAMRICK, J. L. AND GODT, M. J. 1989. Allozyme diversity in plant species. In: Brown, A. H. D., Clegg, M. T., Kahler, A. L. and Weir, B. S. (eds) Plant Population Genetics, Breeding and Genetic Resources, pp. 43-63. Sinauer Associates, Sunderland, MA.

HAMRICK, J. L. AND LOVELESS, M. D. 1986. The influence of seed dispersal mechanisms on the genetic structure of plant populations. In: Estrada, J. and Fleming, T. H. (eds) Frugivores and Seed Dispersal, pp. 211-223. Dr. W. Junk Publishers, Dordrecht.

HAMRICK, J. L., MITTON, J. B. AND LINHART, G. B. 1981. Levels of genetic variation in trees: influence of life history characteristics. In: Conkle, M. T. (ed.) Proc. of the Symposium on Isozymes of North American Forest Trees and Forest Insects, July 27, 1979, Berkeley, California, U.S. Department of Agriculture, Forest Service, Pacific Southwest Forest and Range Experiment Station, Gen. Tech. Rep. PSW-48, pp. 35-41.

HARRISON, R. G. 1986. Pattern and process in a narrow hybrid zone. Heredity, 56, 337-349.

JACOBS, B. F., WERTH, C. R. AND GUTMAN, S. I. 1984. Genetic relationships in Abies (fir) of eastern United States: an electrophoretic study. Can. J. Bot., 62, 609-616.

KING, J. N., DANCIK, B. P. AND DHIR, N. K. 1984. Genetic structure and mating system of white spruce (Picea glauca) in a seed production area. Can. J. Forest Res., 14, 639-643.

KRUTOVSKII, K. V. AND GAFAROV, N. I. 1987. Inheritance of 6-phosphogluconate dehydrogenase in Norway spruce, Picea abies [L.] Karst. Allelic interaction of 6-Pgd-2 and 6-Pgd-3 loci. Genetika (Russian), 23, 2073-2075.

KRUTOVSKII, K. V., POLITOV, D. v. AND ALTUKHOV, Yu. P. 1994. Study of genetic differentiation and phylogeny of stone pine species using isozyme loci. In: Proceedings of the Workshop on Subalpine Stone Pines and Their Environment: The Status of Our Knowledge, St. Moritz, Switzerland, Sept. 5-12, 1992 pp. 19-30. U.S. Dept. Agric. Gen. Tech. Rep. INT-GTR-309. Ogden, UT.

LAGERCRANTZ, U. AND RYMAN, N. 1990. Genetic structure of Norway spruce (Picea abies): concordance of morphological and allozymic variation. Evolution, 44, 38-53.

LEDIG, F. T. 1986. Heterozygosity, heterosis, and fitness in outbreeding plants. In: Soulé, M. E. (ed.) Conservation Biology: the Science of Scarcity and Diversity, pp. 77-104. Sinauer Associates, Sunderland, MA.

LINDQUIST, B. 1948. The main varieties of Picea abies (L.) Karst. in Europe. Acta Horti. Berg., 14, 249-342.

LOVELESS, M. D. AND HAMRICK, J. L. 1984. Ecological determinants of genetic structure in plant populations. Ann. Rev. Ecol. Syst., 15, 65-95.

LUNDKVIST, x. 1974a. Analysis of linkage in Picea abies by means of isozyme analysis. Proc. IUFRO Joint Meeting of Working Parties on Popul. and Ecol. Genet., Breed. Theory and Progeny Testing, SO2.04.1-3, Stockholm, p. 468.

LUNDKVIST, K. 1974b. Inheritance of leucine aminopeptidase isozymes in Picea abies [L.] Karst. Hereditas, 76, 91-96.
LUNDKVIST, $\mathrm{x} .1975$. Inheritance of acid phosphatase isozymes in Picea abies. Hereditas, 79, 221-226.

LUNDKVIST, K. 1979. Allozyme frequency distributions in four Swedish populations of Norway Spruce (Picea abies K.) I. Estimations of genetic variation within and among populations, genetic linkage and a mating system parameter. Hereditas, 90, 127-143.

LUNDKVIST, K. AND RUDIN, D. 1977. Genetic variation in eleven populations of Picea abies as determined by isozyme analysis. Hereditas, 85, 67-74.

MillaR, C. J., STRAUSS, S. H., CONKLE, M. T. AND WESTFALL, R. D. 1988. Allozyme differentiation and biosystematics of the Californian closed-cone pines (Pinus subsect. Oocarpae). Syst. Bot., 13, 351-370.

MORGANTE, M. AND VENDRAMIN, G. G. 1991. Genetic variation in Italian populations of Picea abies [L.] Karst. and Pinus leucodermis Ant. In: Müller-Starck, G. and Ziehe, M. (eds) Genetic Variation in European Populations of Forest Trees, pp. 205-227. J. D. Sauerländer's Verlag, Frankfurt am Main.

MORGANTE, M., vENDRAMIN, G. G. AND GIANNINI, R. 1989. Genetics of 6PGD and SKDH in Norway spruce (Picea abies [L.] Karst.). J. Genet. Breed., 43, 67-71.

MORGANTE, M., VENDRAMIN, G. G. AND ROSSI, P. 1991. Effects of stand density on outcrossing rate in two Norway spruce (Picea abies) populations. Can. J. Bot., 69, 2704-2708.

MÜLLER, G. 1977. Investigations on the degree of natural selffertilization in stands of Norway spruce (Picea abies [L.] Karst.) and Scots pine (Pinus sylvestris L.). Silvae Genet., 26, 207-217.

MÜLlER-STARCK, G., BARADAT, Ph. AND BERGMANN, F. 1992. Genetic variation within European tree species. New Forests, 6, 23-47.

MUONA, O., YAZDANI, R. AND LINDQVIST, G. 1987. Analysis of linkage in Picea abies. Hereditas, 106, 31-36.

MUONA, O., PAULE, L., SZMIDT, A. E. AND KÄRKKÄINEN, K. 1990. Mating system analysis in a Central and Northern European population of Picea abies. Scand. J. Forest Res., 5, 97-102.

NEI, M. 1972. Genetic distance between populations. Am. Nat., 106, 283-292.

NEI, M. 1973. Analysis of gene diversity in subdivided populations. Proc. Natl. Acad. Sci. U.S.A ., 70, 3321-3323.

NEI, M. 1977. F-statistics and analysis of gene diversity in subdivided populations. Ann. Hum. Genet., 41, 225-233.

NEI, M. 1978. Estimation of average heterozygosity and genetic distance from a small number of individuals. Genetics, 89, 583-590.

O'REILLY, G. J., PARKER, W. M. AND CHELIAK, W. M. 1985. Isozyme differentiation of upland and lowland Picea mariana stands in northern Ontario. Silvae Genet., 34, 214-221.

PAULE, L. 1986. Isozyme polymorphism of Norway spruce (Picea abies Karst.) populations from Slovakia. In: Kormutak, A. (ed.) Genepool of Forest Woody Species, its Conservation and Utilization. Proceedings of the International Symposium, pp. 93-106, Nitra, CSSR.

PAULE, L. AND GÖMÖRY, D. 1993. Genetic structure of Norway spruce (Picea abies Karst.) populations from mountainous areas in Slovakia. Lesnictví - Forestry, 39, 10-13. 
PAULE, L., LINDGREN, D. AND YAZDAN1, R. 1993. Allozyme frequencies, outcrossing rate and pollen contamination in $\mathrm{Pi}$ cea abies seed orchards. Scand. J. Forest Res., 8, 8-17.

PAULE, L., SZMIDT, A. E. AND YAZDAN1, R. 1990. Isozyme polymorphism of Norway spruce (Picea abies Karst.) in Slovakia. I. Genetic structure of adjacent populations. Acta Facultatis Forestalis Zvolen, 32, 57-70.

POULSEN, H. D., SIMONSEN, V. AND WELLENDORF, H. 1983. The inheritance of 6 isoenzymes in Norway Spruce (Picea abies L. Karst.). Forest Tree Improv., 16, 12-32.

PRAGER, E. M. AND WILSON, A. C. 1976. Congruence of phylogenies derived from different proteins. A molecular analysis of the phylogenetic position of cracid birds. J. Mol. Evol., 9, 45-57.

PRAVDIN, L. F. 1975. Picea abies (L.) and P. obovata Ledeb. in the USSR. Nauka Publ., Moscow, (Russian).

ROHLF, F. J. 1988. NTSYs-pc: Numerical taxonomy and multivariate analysis system. Exeter Publishing Ltd., New York.

RUBNER, K. 1953. Die pflanzengeographischen Grundlagen des Waldbaues. 4 Aufl. Neumann Verlag, Radebeul and Berlin.

SCHMidT-voGT, H. 1974. Die systematische Stellung der gemeinen Fichte (Picea abies (L.) Karst.) und der sibirischen Fichte ( $P$. obovata Ledeb.) in der Gattung Picea. Allg. Forst- u. J.-Ztg., 3/4, 45-60.

schmidt-vogt, H. 1977. Die Fichte, Band I. Verlag Paul Parey, Hamburg.

SCHOLZ, F. AND BERGMANN, F, 1984. Selection pressure by air pollution as studied by isozyme-gene-systems in Norway spruce exposed to sulphur dioxide. Silvae Genet., 33, 238-240.

SiCiliano, M. J. AND SHAw, C. R. 1976. Separation and visualization of enzymes on gels. In: Smith, I. (ed.) Chromatographic and Electrophoretic Techniques, pp. 185-209. William Heinemann Med. Books Ltd, London.

SNEATH, P. H. A. AND SOKAL, R. R. 1973. Numerical Taxonomy, pp. 230-234. W. H. Freeman, San Francisco.

SWOFFORD, D. L. AND SELANDER, R. B. 1981. BJOSYS-1: a FORTRAN program for the comprehensive analysis of electrophoretic data in population genetics and systematics. J. Hered., 72, 281-283.

TIGERSTEDT, P. M. A. 1973. Studies on isozyme variation in marginal and central populations of Picea abies. Hereditas, 75, 47-60.
TIGERSTEDT, P. M. A. 1979. Genetic adaptation of plants in the subarctic environment. Holarctic Ecol., 2, 264-268.

WELLENDORF, H. 1991. Development of breeding strategies to avoid loss of genetic variation in Norway spruce domestication. In: Müller-Starck, G. and Ziehe, M. (eds) Genetic Variation in European Populations of Forest Trees, pp. 252-270. J. D. Sauerländer's Verlag, Frankfurt am Main.

WHEELER, N. C., GURIES, R. P. AND O'MALLEY, D. M. 1983. Biosystematics of the genus Pinus, subsection Contortae. Biochem. Syst. Evol., 11, 333-340.

WILKINSON, L. 1987. sYSTAT: The System for Statistics. SYSTAT, Inc., Evanston, IL.

wOODRUFF, D. S. 1989. Genetic anomalies associated with Cerion hybrid zones: the origin and maintenance of new electromorphic variants called hybrizymes. Biol. J. Linn. Soc., 36, 281-294.

WRIGHT, s. 1978. Evolution and the Genetics of Populations, vol. 4, Variability within and Among Natural Populations. University of Chicago Press, Chicago.

von WUELISCH, G. AND KRUSCHE, D. 1991. Single and multilocus genetic effects on diameter growth in Picea abies (L.) Karst. In: Fineschi, S., Malvolti, M. E., Cannata, F. and Hattemer, H. H. (eds) Biochemical Markers in the Population Genetics of Forest Trees, pp. 77-86. SPB Academic Publishing bv., The Hague.

XIE, C. Y. AND KNOWLES, P. 1992. Male fertility variation in an open-pollinated plantation of Norway spruce (Picea abies). Can. J. Forest Res., 22, 1463-1468.

YEH, F. C. 1981. Analysis of gene diversity in some species of conifers. In: Proc. of the Symposium on Isozymes of North American Forest Trees and Forest Insects, July 27, 1979, Berkeley, California, U.S. Department of Agriculture, Forest Service, Pacific Southwest Forest and Range Experiment Station, Gen. Tech. Rep. PSW-48, pp. 48-52.

YEH, F. C. AND ARNOTT, J. T. 1986. Electrophoretic differentiation of Picea sitchensis, Picea glauca and their hybrids. Can. J. Forest Res., 16, 791-798.

YEH, F. C. AND EL-KASSABY, Y. A. 1980. Enzyme variation in natural populations of sitka spruce (Picea sitchensis). I. Genetic variation patterns among trees from 10 IUFRO provenances. Can. J. Forest Res., 10, 415-422.

YEH, F. C., KHALIL, M. A. K., EL-KASSABY, Y. A. AND TRUST, D. C. 1986. Allozyme variation in Picea mariana from Newfoundland: genetic diversity, population structure, and analysis of differentiation. Can. J. Forest Res., 16, 713-720. 